5. Иваницкий Г.К., Недбайло А.Е. Аналитическое исследование кавитации в рабочем колесе центробежных насосов // Промышленная теплотехника. - 2012. - Т. 34, № 2. - C. $40-47$

6. Ashokkumar M, Rink R., Shestakov S. Hydrodynamic cavitation - an alternative to ultrasonic food processing. // Electronic Journal “Technical Acoustics” http://ejta.org, 2011. - № 9. - P. 1 - 10.

\title{
Reference
}

1. Dolinsky A.A., Ivanitsky G.K. Heat and mass transfer and hydrodynamics in vapor-liquid dispersed media. (2008), Kiev, Naukova dumka, 381

2. Jitendra Carpenter, Mandar Badve, Sunil Rajoriya, Suja George, Virendra Kumar Saharan and Aniruddha B. Pandit. (2016). Hydrodynamic cavitation: an emerging technology for the intensification of various chemical and physical processes in a chemical process industry. Reviews in Chemical Engineering. 10. 3 - 37.

3. Farid Chemat, Natacha Rombaut, Anne-Gaëlle Sicaire, Alice Meullemiestre, Anne-Sylvie Fabiano-Tixier, Maryline Abert-Vian.( 2017) Ultrasound assisted extraction of food and natural products. Mechanisms, techniques, combinations, protocols and applications. A review. Ultrasonics Sonochemistry. 34. 540 -560.

4. Chisti Yu., Moo-young M. (1986). Disruption of microbial cells for intracellular products. Review Enzyme Microbiol. Techn. 8. $194-204$.

5. Ivanitsky G.K., Nedbaylo A.E. Analytical study of cavitation in the impeller of centrifugal pumps. Industrial Heat Engineering, Kiev, (2011), 34(2), $40-47$.

6. Ashokkumar M., Krasulya O., Rink R. A New Look at Cavitation and the Applications of Its Liquid-Phase Effects in the Processing of Food and Fuel, Appl. Phys. Research, (2012), 4(1), 19 - 29.

Отримано в редакцію 27.04.2018

Прийнято до друку 01.07.2018
Received 27.04.2018

Approved 01.07.2018

DOI: http://dx.doi.org/10.15673/swonaft.v82i1.998

\section{ДОСЛІДЖЕННЯ СТІЙКОСТІ ТЕЧІЇ ГРАВІТАЦІЙНО СТІКАЮЧОЇ ПЛІВКИ РІДИНИ В ДВОФАЗНИХ СИСТЕМАХ}

\author{
Туз В.О. ${ }^{1}$, д.т.н., ЛебедьН.Л ${ }^{1}$,, к.т.н. \\ ${ }^{1}$ Національний технічний університет України \\ «Київський політехнічний інститут імені Ігоря Сікорського» \\ м. Київ, Україна
}

\begin{abstract}
Анотація. Використання методів пасивної інтенсифікацї̈ у вигляді поверхонь з капілярно-пористим покриттям в контактних апаратах істотно ускладнює гідродинамічну картину взаємодії системи «поверхня - плівка рідини - газовий потік». Інтенсифікуючи прочеси тепло- і масообміну, штучна шорсткість зменшує робочий діапазон контактних апаратів, шляхом зниження границі захлинання. Результати рішення математичної моделі системи «плівка рідини - газовий (паровий) потік» у вигляді системи диференціальних рівнянь з відповідними граничними умовами для гладкої вертикальної поверхні не коректно використовувати для визначення параметрів плівки при кризових явищах у випадку застосування каналів з капілярно-пористими структурами. Представлений аналіз результатів експериментального дослідження гідродинаміки двофазного потоку в каналах з капілярно-пористим покриттям, при відповідних граничних умовах, дозволив визначити верхній діапазон навантажень до початку захлинання по рідкій $і$ газовій фазах в контактних тепломасообмінних апаратах. Аналітичне рішення задачі з визначення гранищь кризових явищ з урахуванням результатів експериментального дослідження гідродинаміки двофазного потоку в каналах з капілярно-пористим покриттям, при відповідних граничних умовах, дозволило визначити верхній діапазон навантажень до початку захлинання по рідкій $і$ газовій фазах в контактних тепломасообмінних апаратах.
\end{abstract}

Ключові слова: гідродинаміка, плівка рідини, капілярно-пориста структура, границя захлинання

\section{STUDY OF FLOW STABILITY OF GRAVITATIONALLY FLOWING LIQUID FILM IN A TWO-PHASE SYSTEMS}

\author{
doctor of science V.O.Tuz ${ }^{1}$, candidate of technical sciences N.L.Lebed ${ }^{1}$ \\ ${ }^{1}$ National Technical University of Ukraine \\ "Igor Sikorsky Kiev Polytechnic Institute" \\ Ukraine, Kyiv
}

\begin{abstract}
The use of passive intensification methods in the form of surfaces with a capillary-porous coating in contact devices greatly complicates the hydrodynamic structure of the interaction of the system "surface liquid film - gas stream". Intensifying the processes of heat and mass transfer, artificial roughness increases the working range of contact devices, by reducing the break border.

The complexity of the analytical study of the stability of the system "liquid film - gas or steam flow" by solving a mathematical model, which is a system of differential equations with corresponding boundary conditions, consists in the fact that the functional dependence for the boundary phase separation is unknown. By using the
\end{abstract}

Наукові праці, Том 82, випуск 1
Scientific Works, Volume 82, Issue 1 
equation of the surface separation in the form of a wave function that satisfies this system of differential equations and boundary conditions, it is necessary to determine the parameters of the waves. It is assumed that the tangential and normal components of the gas stress on the surface of the liquid film can be expressed by the dependence due to the deviation of the phase separation surface from the liquid-film-unshaked waves. Under such assumptions, the solution is reduced to considering the motion of a liquid film at given boundary conditions on the channel wall and on a free surface.

The results of the solution of mathematical model of system "liquid film - gas (steam) flow" for a smooth vertical surface are not correctly used to determine the film parameters at crisis phenomena's in the case of channels with a capillary-porous structure.

The represented analysis of results of the experimental study of the hydrodynamics of two-phase flow in the channels with capillary-porous coating, at the appropriate boundary conditions, allowed to determine the upper range of loads prior to the beginning of break on the liquid and gas phases in contact heat and mass exchange devices. An analytical solution to the task of determining the boundaries of crisis phenomena, taking into account the results of an experimental study of the hydrodynamics of a two-phase flow in channels with capillaryporous coating, at appropriate boundary conditions, allowed to determine the upper range of loads prior to the beginning of break on the liquid and gas phases in contact heat and mass exchange devices.

Keywords: hydrodynamics, liquid film, capillary-porous structure, chocking boundary

Вступ. Складність фізичної моделі контакту гравітаційно стікаючої плівки 3 потоком газу, вплив конструктивних характеристик поверхонь, теплофізичних властивостей і режимних параметрів контактуючих фаз вимагають свідомо спрощувати аналітичні моделі, або досліджувати процес експериментально.

Формулювання задачі і аналіз літературних джерел. Нестійкість руху плівки рідини і потоку газу спостерігається в певному діапазоні швидкості газу. Нижня границя цього діапазону відповідає виникненню режиму захлинання, а верхня - стійкому висхідному руху фаз. Аналітичне дослідження стійкості системи «плівка рідини - газовий або паровий потік» розглянуто в [1]. Складність рішення представленої задачі у вигляді системи диференціальних рівнянь з відповідними граничними умовами полягає в тому, що функціональна залежність для границі розділу фаз невідома. Задаючи рівняння поверхні розділу у вигляді хвильової функції, яка задовольняє даній системі диференціальних рівнянь і граничним умовам, необхідно визначити параметри хвиль. Допускається, що дотична і нормальна складові напруги з боку газу на поверхні плівки рідини можуть бути виражені залежністю через відхилення поверхні розділу фаз від площини $\delta=\delta_{0}$, що відповідає поверхні незбуреної хвилями плівки рідини. При таких допущеннях рішення зводиться до розгляду руху плівки рідини при заданих граничних умовах на стінці каналу і на вільній поверхні.

В результаті рішення цієї задачі в [2] отримано характеристичне рівняння для частотної характеристики плівкової течії. Аналіз рішення показав, що стійкий хвильовий рух можливий лише в області малих значень безрозмірної товщини плівки. Кожному значенню безрозмірної товщини плівки відповідає два значення критичної довжини хвилі $\lambda_{\text {кр }} / \delta_{0}$. Більше значення відповідає початку появи хвиль на гладкій поверхні. Менше - малим довжинам хвиль і характеризує втрату стійкості хвильового руху при збільшенні швидкості газового потоку. В цьому випадку зростає амплітуда хвиль, що приводить до порушення стійкості течії і відриву крапель рідини з гребенів хвиль. Цей режим відповідає нижній границі процесу захлинання. Фіксація початку цього режиму можлива по різкому збільшенню опору. Функціонально границі режиму захлинання можна представити у вигляді залежності критичної довжини хвилі від безрозмірної товщини плівки і безрозмірної дотичної напруги на границі «рідина - газ».

Як встановлено в результаті теоретичного аналізу [1] порушення хвильової течії, гранична товщина плівки рідини, характеризується постійним значенням відносної довжини хвилі.

Використання методів пасивної інтенсифікації у вигляді шорстких поверхонь в контактних апаратах істотно ускладнюють гідродинамічну картину взаємодії системи «поверхня - плівка рідини - газовий потік». Інтенсифікуючи процеси тепло- і масообміну, штучна шорсткість зменшує робочий діапазон контактних апаратів, шляхом зниження границі захлинання. Аналогічна ситуація спостерігається і при використанні капілярно-пористих матеріалів. Використання залежностей для визначення товщини плівки рідини на вертикальній гладкій поверхні, стосовно поверхонь з регулярною шорсткістю, з пористим або капілярно-пористим покриттями не коректно і вимагає відповідного дослідження.

На відміну від випадку гравітаційної течії плівки по вертикальній гладкій поверхні гідродинаміка течії рідини по вертикальній поверхні з капілярно-пористим покриттям при зміні густини зрошення має суттєві відмінності.

Результати експериментальних досліджень. Аналіз експериментальних даних дозволив виділити характерні області ламінарного руху плівки рідини по вертикальній поверхні з капілярно-пористим покриттям у вигляді сітки [3]. Перша область характеризується монотонною зміною товщини плівки залежно від щільності зрошування. Такий характер зміни товщини плівки відбувається у разі повного затоплення капілярно-пористої структури. Функція зміни товщини плівки на стінці з капілярно-пористим пок- 
риттям узгоджується з залежністю для товщини ламінарної гравітаційно стікаючої плівки на гладкій вертикальній поверхні, яка отримана в роботах В.Нуссельта. Для цієї області нижня границя діапазону визначається щільністю зрошування, при якій відбувається затоплення капілярно-пористої структури. Подальше збільшення щільності зрошування приводить до зростання товщини плівки. Слід зазначити, що характер залежності ідентичний зміні товщини плівки при течії плівки у вертикальних каналах 3 гладкими стінками.

Друга область характеризується відносно стабільною товщиною плівки. Зміна щільності зрошування не приводить до значної зміни ії товщини. В цій області домінують сили поверхневого натягу, які утримують плівку в структурі капілярно-пористого покриття. Діапазон зміни товщини плівки для цієї області характеризується початком появи верхньої частини дроту в місці їх переплетення і товщиною плівки в центрі меніска, утвореного рідиною між дротами вічка сітки.

При подальшому зменшенні щільності зрошування в третій області відбувається стрибкоподібна зміна товщини плівки. Очевидно, що в цій області баланс сил складається таким чином, що сили інерції стають меншими ніж сили когезії. Нижня границя цієї області характеризується плівковою течією рідини по гладкій поверхні труби і наявністю менісків під нижньою поверхнею дротів вічка сітки.

Для четвертої області характерним є відносно стабільний рух плівки. Товщина плівки в цій області близька до мінімально допустимої і при невеликій зміні щільності зрошування відбувається розрив плівки з утворенням сухих плям і переходом в струмкову течію.

Враховуючи складний характер зміни товщини плівки при іï течії по стінках вертикального каналу 3 капілярно-пористим покриттям стінок, обумовлений дією капілярних сил, найбільш сприятливою з точки зору умов роботи тепломасообмінного обладнання є друга область діапазону щільності зрошування. Розвиток кризового явища, границею якого є початок процесу захлинання, супроводжується активною взаємодією на поверхні розділу фаз. Це приводить до втрати стійкості хвильового руху і початку активного крапельного виносу. Такий режим характеризується мінімальним значенням коефіцієнта опору $\xi_{\text {оп }}$

Аналітичне рішення задачі з визначення границь кризових явищ, отримане в [1], було уточнено 3 урахуванням результатів експериментального дослідження гідродинаміки двофазного потоку в каналах 3 капілярно-пористим покриттям, при відповідних граничних умовах [4].

Для фіксації гідродинамічної картини двофазної течії контролювався поздовжній градієнт повних втрат тиску $\Delta \mathrm{P} / \mathrm{L}$, який визначався як відношення загального перепаду тиску в потоці $\Delta \mathrm{P}$ до відстані між відборами L. У якості капілярно-пористого покриття використовувалась сітка, зміна геометричних характеристик якої, зокрема, збільшення діаметру дроту $d_{\text {др }}$ і розміру вічка $\mathrm{S}$, приводить до зростання коефі-

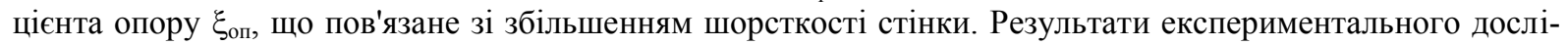

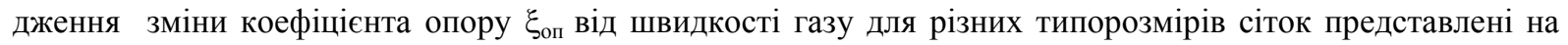
рис. 1.

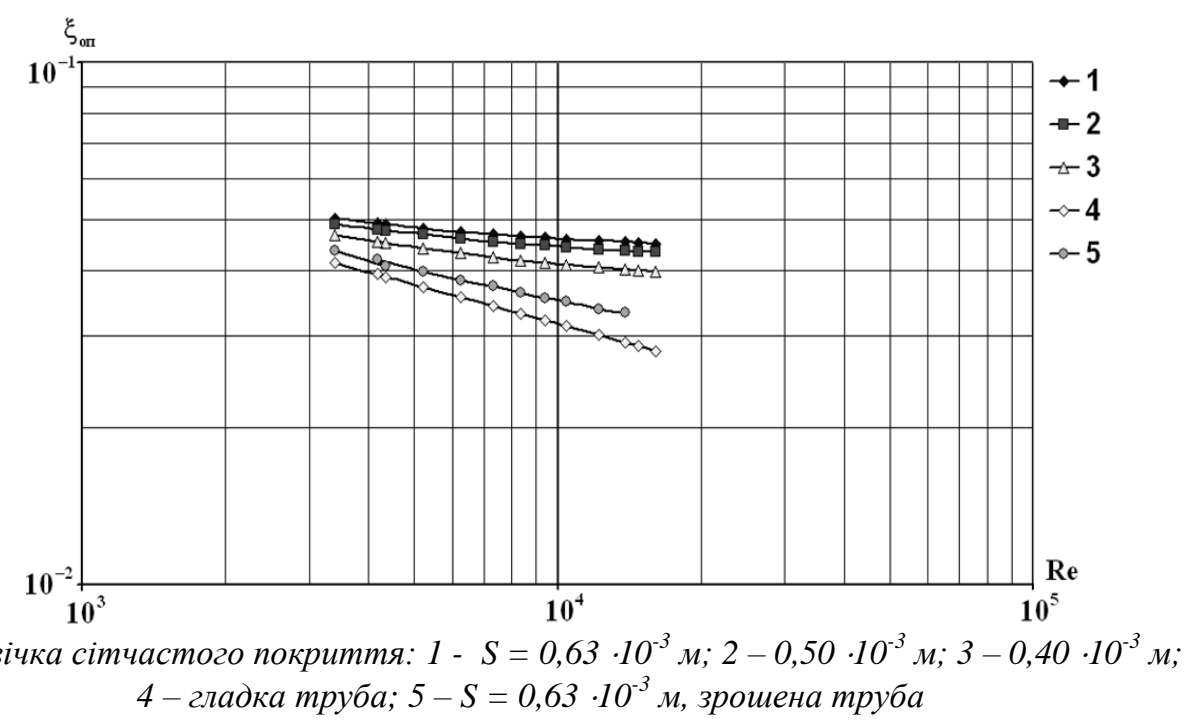

Рис. 1. Зміна коефіціснту опору каналу із капілярно-пористим покриттям в залежності від швидкості газового потоку.

На відміну від процесів, які відбуваються в каналах з гладкими стінками, розвиток гідродинамічної кризи в каналах з сітчастим покриттям має свої особливості. Аналіз експериментальних даних показав,

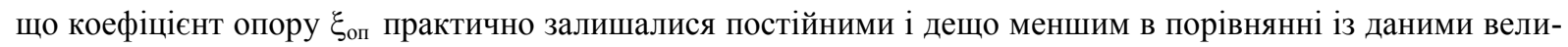
чин у разі відсутності зрошування.

Такий характер взаємодії плівки з газовим потоком зберігається до того моменту поки рідина не виходить за межі товщини капілярно-пористого покриття, тобто $\delta^{*}<\delta{ }_{3}$. 
Пояснюється це зменшенням впливу шорсткості внаслідок затоплення плівкою капілярно-пористого покриття в другій області.

Співвідношення балансу масових витрат плівки рідини і газового потоку, яке визначає нижню границю процесу захлинання, залежну від щільності зрошування, геометричних характеристик каналу, розміру сітки і фізичних властивостей рідини і газу, узагальнюється залежністю з похибкою $\pm 7 \%$

$$
\mathrm{K}_{\mathrm{w}_{\mathrm{\kappa p}}}=2,09 \cdot \mathrm{Fr}^{-0,4} \cdot \mathrm{Bo}^{0,5}
$$

В результаті проведених досліджень по визначенню порушення стійкості режимів руху двофазного потоку, складені карти режимів течії. Виділяючи зі всього спектру можливих режимів тільки режими, характерні для роботи контактних тепломасообмінних апаратів, а саме режими, при яких здійснюється протитечійний рух гравітаційно стікаючих плівок і потоку газу до кризового явища, що супроводжується зривом крапель рідини з поверхні плівки і при цьому характеризується мінімальним значенням коефіціє-

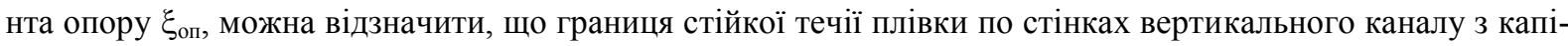
лярно-пористим покриттям значно розширена в порівнянні з каналами, що мають гладкі стінки.

Слід зазначити, що із зростанням характерного розміру сітки $\left(S / d_{\text {др }}\right)$ у діапазоні досліджень розширюються границі сталої роботи контактних апаратів.

Таким чином, аналітичне рішення задачі з визначення границь кризових явищ, отримане Безродним М.К. у [1], з урахуванням результатів експериментального дослідження гідродинаміки двофазного потоку в каналах 3 капілярно-пористим покриттям, при відповідних граничних умовах, дозволяє визначати верхній діапазон навантажень до початку захлинання по рідкій і газовій фазах в контактних тепломасообмінних апаратах. При цьому, початок процесу захлинання наступає при значно більшій товщині плівки, що є істотною позитивною характеристикою запропонованого методу інтенсифікації процесів тепломасообміну.

\section{Висновки.}

1. Дослідження моделі взаємодії в кільцевих двофазних системах і визначення умов збереження стійкості плівкової течії при протитоковому русі газу і рідини у вертикальних каналах 3 капілярнопористим покриттям з використанням рівнянь Навьє-Стокса і нерозривності для рідини і газу підтвердило, що причини кризи, пов'язаної з втратою стійкості хвильового руху при затопленій капілярнопористій структурі, аналогічні процесам, що відбуваються в каналах з гладкими стінками. Слід зазначити також, що наявність пористого або капілярно-пористого покриття на поверхні каналів, яке можна розглядати як регулярну шорсткість, приводить за певних умов, до інтенсифікації хвильових процесів в плівці i, тим самим, зниження нижньої границі початку процесу захлинання.

2. Гідравлічний опір каналів з сітчастим покриттям стінок залежить від режиму руху газового потоку і геометричних характеристик сіток. Отримані експериментальні дані, в досліджуваному діапазоні швидкостей, дозволяють визначити коефіцієнт опору аналогічно, як і для труб з природною шорсткістю. Наявність плівкової течії в діапазоні щільності зрошування, характерної для другої, третьої та четвертої областей, призводить до деякого зниження гідравлічного опору внаслідок затоплення капілярно-пористої структури і зменшення висоти виступів регулярної шорсткості.

3. Гідродинамічна криза гравітаційно стікаючої плівки і висхідного потоку газу, яка відповідає початку процесу захлинання, залежить від щільності зрошування, геометричних характеристик каналу і капілярно-пористого покриття, фізичних властивостей рідини і газу. Фіксувалась гідродинамічна криза по мінімальному значенню коефіцієнта опору $\xi_{\text {оп }}$.

Експериментальні дані з визначення нижньої границі процесу захлинання, які узагальнені залежністю (1), показали, що границя сталої течії плівки по стінках вертикального каналу з капілярно-пористим покриттям значно розширена в порівнянні з каналами, що мають гладкі стінки.

4. Аналітичне рішення задачі з визначення межкризових явищ, отримане в [1], було уточнено 3 використанням результатів експериментального дослідження гідродинаміки двофазного потоку в каналах 3 капілярно-пористим покриттям. При цьому, початок процесу захлинання наступає при значно більший товщині плівки, що є істотним позитивним моментом при експлуатації контактних тепломасообмінних апаратів.

\section{Література.}

1. Безродный М.К., Пиоро И.Л., Костюк Т.О. Процессы переноса в двухфазных термосифонных системах. Київ: Факт, 2003. $480 \mathrm{c}$.

2. Семёнов П.А. Течение жидкости в тонких слоях (II). Журнал теоретической физики. 1950. Т. 20., вып. 8. С. $980-990$.

3. Безродный М.К., Письменный Е.Н., Туз В.Е., Лебедь Н.Л. Экспериментальное исследование гидродинамики плёночного течения в каналах с сеточным покрытием. Промышленная теплотехника. 2009. Т.31, № 7. С. 139-143.

4. Безродный М.К., Письменный Е.Н., Туз В.Е., Лебедь Н.Л. Аналитическая модель разрыва плёнки жидкости при гравитационном течении по вертикальным поверхностям с сеточным покрытием. Промышленная теплотехника. 2009. Т.31, № 6. С. 21-27.

References

1. Bezrodny M.K., Pioro I.L., Kostyuk T.O. Transfer processes in two-phase thermosyphon systems. Kyiv: Fakt, 2003. 480 .

2. Semenov P.A. The flow of liquid in thin layers (II). Journal of Theoretical Physics. 1950. 20(8), 980-990. 
3. Bezrodny M.K, Pismenny E.N., Tuz V.E., Lebed N.L. Experimental study of hydrodynamics of film flow in channels with a grid coating. Industrial Heat Engineering. 2009. 31(7), 139-143.

4. Bezrodny M.K., Pismenny E.N., Tuz V.E., Lebed N.L. Analytical model of liquid film rupture during gravitational flow along vertical surfaces with a grid coating. Industrial Heat Engineering. 2009. 31(6), 21-27.

\title{
ІНТЕНСИФІКАЦІЯ ПРОЦЕСУ СУШІННЯ РОСЛИННОЇ СУМIШI 3 СОÏ ТА БАТАТУ
}

\author{
Петрова Ж.О., д.т.н, головний науковий співробітник \\ Слободянюк К.С., аспірант \\ Інститут технічної теплофізики НАН України, м. Київ
}

\begin{abstract}
Аннотация. Постійний попит на сою і соєві продукти як на внутрішньому, так $i$ зовнішньому ринках Украйни зумовив розширення площзі посівів під иією рослиною і вона стала одною з найприбутковіших культур, які вирощуються у сільськогосподарських підприємствах. Полінасичені жирні кислоти, які входять до складу клітинних мембран сої та інших структурних елементів рослинних тканин, виконують 8 організмі низку важливих функиій, зокрема забезпечують нормальний ріст та обмін речовин, еластичність судин. У зв'язку з існуючою проблемою дефіииту білка в харчуванні людей все більшої актуальності набувають для Украӥни дослідження шляхів підвищення економічної ефективності виробництва сої, формування та функиіонування ринку сої та продуктів ії переробки.

Тепловий вплив - одна з найбільш широко розповсюджених теплотехнологічних операцій в процесах обробки рослинної сировини, а тепловий нагрів з метою зменшення початкового вологовмісту сировини, щуо оброблясться (сушіння) - один із найбільш розповсюджених способів консервування, підготовки $i$ полуфабрикування харчових продуктів. На ряду з перевагами процесу сушіння виникає ряд недоліків процесу, найважливішим з яких, в сучасних умовах, є енерговитрати на виконання процесу. Процес сушіння один з найбільш енергоємних операиії, він використовує до 25\% всієї промислової енергії. Через проблеми в екологічній і енергетичній галузях, включаючи викиди парникових газів, виснаження викопного палива тощь стає надзвичайно важливим зменшення споживання енергії у всіх галузях промисловості.

Створення рослинних композицій, поєднання двох сумісних за біохімічним складом матеріалів (сої та батату), дає можливість знизити енерговитрати на процес сушіння та зберегти біологічно активні речовини в прочесі зберігання висушеної сировини. За своїм біохімічним складом батат містить каротиноїди, щео є природніми стабілізаторами для білків сої і які перешкоджають окисленню ї̈ ліпідів. Отже, поєднання ичих двох компонентів дозволяє природнім шляхом збільшити термін зберігання сировини. Через відсутність інформації в наукових інформаційних джерелах про вплив режимних параметрів сушіння $(t, \varphi, v)$ на кінетику сушіння соєво - бататної суміші, ия робота спрямована на дослідження процесу сушіння соєво - овочевих композицій з метою інтенсифікаиії процесу.
\end{abstract}

Ключові слова: теплотехнологія, білок, соя, сушіння, зберігання.

\section{INTENSIFICATION OF THE PROCESS OF DRYING VEGETABLE COMPOSITION FROM SOY AND BATAT \\ Petrova Zh.O., Doctor of Engenering., Chief researcher Slobodyanyuk K.S., post-graduate student \\ Institute of Technical Thermophysics of the National Academy of Sciences of Ukraine, Kyiv}

\begin{abstract}
The constant demand for soy and soya products on both the domestic and foreign markets of Ukraine led to the expansion of the area under this plant and became one of the most profitable crops grown in agricultural enterprises. Polyunsaturated fatty acids, which are part of cellular soybean membranes and other structural elements of plant tissues, perform in the body a number of important functions, in particular, provide normal growth and metabolism, elasticity of blood vessels. Due to the existing problem of protein deficiency in people's nutrition, Ukraine is increasingly studying ways to increase the economic efficiency of soybean production, the formation and functioning of the soy market and its processing products.

Thermal effect is one of the most widely used heat engineering operations in the process of processing of plant raw materials, and heat heating in order to reduce the initial moisture content of processed material (drying) - one of the most common methods of preservation, preparation and semi-preparation of food products.
\end{abstract}

